\title{
ESTETIKA SASTRA POPULER DALAM NOVEL MENCARI SARANG ANGIN KARYA SUPARTO BRATA
}

\author{
Dheny Jatmiko \\ Dosen Sastra Inggris Fakultas Sastra \\ Universitas Tujuh Belas Agustus 1945 Surabaya \\ sebelasdheny@gmail.com
}

This research's title is Estetika Sastra Populer d Novel Mencari Sarang Angin Karya Suparto Brata. This research is aiming to elaborate the story of Mencari Sarang Angin by Suparto Brata. This research is done because Suparto Brata and his novels are containing historical story but, different with the other historical novels, appreciation and legitimation that received by Suparto Brata is not relatively significant.Mencari Sarang Angin is one of Suparto Brata's popular work, that is the reason why this work becomes the object study. There are some theories that is used, they are cultural production by Bourdieu and detective formula theory. According to this research, there are two findings, they are dominant love story as the main story, also utilization of detective story formula as the structure of story telling.

Keywords: Mencari Sarang Angin, Suparto Brata, detective story, arena

\begin{abstract}
Abstrak
Penelitian berjudul Estetika Sastra Populer dalam Novel Mencari Sarang Angin Karya Suparto Brata ini menguraikan formula cerita dalam novel Mencari Sarang Angin karya Suparto berikut pemaknaan terhadapnya. Penelitian dilakukan karena Suparto Brata dan novel-novel yang ditulisnya relatif kerap dianggap memuat kisah-kisah sejarah namun, tidak seperti penulis novel sejarah lainnya, apresiasi dan legitimasi yang didapatkan Suparto Brata relatif kurang signifikan. Mencari Sarang Angin merupakan salah satu karya Suparto Brata yang terkemuka, dan oleh karenanya dijadikan objek kajian. Adapun teori yang digunakan dalam penelitian ini adalah teori arena produksi kultural Bourdieu dan formula teori detektif. Berdasarkan penelitan ini dapat ditemukan bahwa Mencari Sarang Angin memang merupakan karya sastra populer. Hal ini dibuktikan melalui dua temuan, yaitu penghadiran kisah cinta yang begitu dominan dan menjadi pusat cerita; juga pemanfaatan formula cerita detektif sebagai struktur penceritaan.
\end{abstract}

Kata Kunci: Mencari Sarang Angin, Suparto Brata, Cerita detektif, Arena

\section{PENDAHULUAN}

Novel Mencari Sarang Angin (MSA) karya Suparto Brata MSA merupakan novel yang berisi sejarah nasional dan lokalitas Surabaya. Oleh karena itu, tidak mengherankan jika ada yang menempatkan MSA sebagai karya sastra serius. Bahkan ketika MSA telah dicetak menjadi buku pada tahun 2005, desain sampul dengan warna suram (coklat kehitaman) dengan gambar seorang laki-laki terpelajar dan tangan-tangan yang mengepal merupakan tipikal bentuk sastra serius. Pun 
juga kutipan di sampul belakang yang lebih mengarahkan bahwa novel MSA berisi tentang perjuangan tokoh dalam mengkritisi dan mengubah budaya tradisional Jawa.

Penghadiran historisitas dan lokalitas pada novel-novel karya Suparto Brata relevan dengan pandangan Suparta Brata mengenai karya sastra. Karya sastra, bagi Suparto Brata, merupakan media dokumentasi pengalaman dan pengetahuannya. Suparto Brata sebagai pelaku sejarah memberi kontribusi dalam memahami sejarah bangsa Indonesia untuk generasi setelahnya melalui karya sastra. Oleh karenanya karya-karya Suparto Brata banyak berisi tentang data-data historis, baik peristiwa besar maupun peristiwa kecil. Dalam MSA, selain peristiwa kolonialisasi, kemerdekaan, dan PKI sebagai narasi besar, ditemukan juga data-data mengenai kehidupan masyarakat Surabaya antara lain adat perkawinan masyarakat Surabaya, permainan adu doro, dan kegemaran pada parikan.

Sejarah nasional dan lokal menjadi salah satu modal kultural Suparto Brata dalam kontestasi simbolik di arena sastra Indonesia sekaligus menjadi salah satu strategi untuk masuk pada posisi dominan. Pasalnya karya-karya sejenis ini merupakan karya sastra yang mendapatkan legitimasi sastra, salah satu yang paling terkenal adalah Pramoedya Ananta Toer. Oleh karena itu, kemunculan MSA, dengan historitas dan lokalitas tersebut, secara tidak langsung menempatkan karya-karya Suparto Brata dalam wilayah sastra serius.

Di lain pihak, jika dilihat dari porsi penghadiran cinta dan formula cerita yang digunakan mengindikasikan bahwa MSA merupakan karya sastra populer. Novel MSA, dilihat dari kisah tokoh utamanya, menceritakan perjuangan Darwan untuk mendapatkan uang dan cinta dalam perubahan-perubahan kekuasaan. Darwan, sebagai tokoh utama, tidak melibatkan diri pada persoalan nasionalisme ${ }^{1}$. Nasionalisme merupakan kisah dari tokoh-tokoh figuran seperti Yayi, Slamet, Tuan Ayat, Kobar, dan Sajiwa. Tokoh utama memilik peranan penting dalam sebuah cerita, yaitu sebagai penyampai utama tema dan gagasan cerita. Oleh karena itu, novel MSA akan lebih tepat jika disebut sebagai 'novel yang berlatar belakang sejarah dan lokalitas Surabaya'.

Berdasar pemaparan di atas, muncul hipotesis bahwa MSA dibangun dengan menggunakan formula estetika sastra populer. Dengan pemanfaatan historisitas dan lokalitas sebagai latar belakang cerita tidak serta merta menempatkan MSA dalam wilayah 'sastra serius'. Dengan

\footnotetext{
${ }^{1}$ Dalam karya sastra yang menggunakan latar sejarah Indonesia, terutama pada masa kolonialisme Hindia Belanda, seringkali menempatkan tokoh utamanya sebagai tokoh yang memiliki pandangan dan tindakan nasionalisme.

Sebagai contoh adalah tokoh Minke dalam Bumi Manusia karya Pramoedya
} 
demikian, penelitian ini bermaksud memaparkan serta menganalisis secara lebih mendalam tentang struktur cerita MSA dengan menggunakan formula sastra populer, sehingga hipotesis tersebut dapat dibuktikan.

\section{SASTRA POPULER}

Sastra Indonesia dibagi menjadi dua arus utama, yaitu sastra serius dan sastra populer. Sastra serius seringkali ditandai dengan adanya legitimasi dari lembaga atau kelompok yang dipandang memiliki kompetensi sebagai 'badan legitimasi sastra', misalnya Balai Pustaka pada masa pemerintahan kolonial, Dewan Kesenian Jakarta, dan kelompok Horison. Sedangkan sastra populer adalah sastra yang cenderung 'terpinggirkan' atau berada di luar lembaga atau kelompok tersebut tetapi beredar luas di masyarakat. Di antara keduanya memang ada perbedaan visi dan misi.

Bourdieu (2010: 17) membedakan keduanya dengan menyebut bahwa sastra 'serius' menggunakan prinsip 'otonom', sedangkan sastra populer menggunakan prinsip 'heteronom'. Prinsip hierarki otonom adalah derajat konsekrasi yang spesifik (prestise kesuastraan atau artistik), yakni derajat pengakuan yang diterima oleh lembaga legitimasi. Prinsip hirearki heteronom adalah kesuksesan, sebagaimana dapat diukur dengan inkes-indeks seperti angka penjualan buku. Sementara Gelder (2004: 19) menyebutkan bahwa sastra serius menunjukkan kompleksitas, sedangkan sastra populer lebih pada kesederhanaan. Keduanya menawarkan kenikmatan dengan karakteristik yang khas, artinya bahwa pengalaman yang didapat ketika membaca sastra 'serius' akan jauh berbeda jenisnya dengan pengalaman membaca sastra populer. Sastra serius lebih erat kaitannya dengan kehidupan, sedangkan sastra populer lebih pada fantasi.

Hal ini dipertajam oleh Kayam (1981: 88) dengan meyatakan bahwa sastra populer merupakan perekam kehidupan yang tidak banyak membincangkan kembali dalam serbakemungkinan. Penulis sastra populer memilih rekaman tentang kehidupan, menyajikan kembali, dengan perhitungan pembacanya akan banyak mengenal kembali pengalamanpengalamannya hingga terhibur. Adapun sastra yang 'sastra' atau sastra 'serius' (untuk menyebut sastra luhur) tidak sekedar merekam kembali, tetapi membincangkan kembali melalui manipulasi, dan rasa sastra.

Sastra serius memberikan banyak kemungkinan makna penceritaan; sastra populer lebih pada pemenuhan kebutuhan hiburan. Oleh karenanya, penulis sastra serius cenderung tidak banyak 
memproduksi (menciptakan) buku. Pun demikian, karya sastra serius seringkali mampu melampaui ruang dan waktu, karena yang ditonjolkan merupakan sikap terhadap realitas. Rampan (2009) menyatakan bahwa karya sastra lahir dari kesatuan utuh antara getaran jiwa penulisnya dengan alam semesta, lingkungan dan obyeknya. Penulis novel dan cerpen tidak mau berkompromi dengan selera pasar/massa. Tidak masalah apabila yang ditulis itu tidak disukai atau tidak dipahami pembaca. Yang penting penulis telah mencurahkan ide dan tanggapan terhadap hidup dan kehidupan dengan tetap mempertimbangkan kualitas karya yang indah, kreatif, dan orisinil.

Kondisi ini berbeda dengan sastra populer yang cenderung terkenal atau digemari pada waktu tertentu atau bersifat sesaat. Fiksi populer tidak terlalu terkait dengan wacana kreativitas dan orisinalitas, dan lebih berkaitan dengan produksi dan kerja keras. Paradigma utama untuk mengidentifikasi fiksi populer bukanlah kreativitas, tetapi industri (Gelder, 2004: 15). Penulis sastra populer dapat memiliki produktivitas penciptaan karya yang begitu tinggi. Namun penciptaan tersebut lebih menekankan pada reproduksi, dimana kebaruan karya hanya dimunculkan melalui sedikit variasi, misalnya pada latar, bukan pada gagasan cerita.

Pembicaraan tentang sastra populer tidak dapat dilepaskan dari budaya populer. Adorno menyatakan bahwa kebudayaan industri telah mendominasi dan menentukan seni dan kebudayaan yang sesuai dengan apa yang diinginkan. Apa yang disebut baru dalam kebudayaan industri bukanlah sesuatu yang benar-benar baru. Elemen utama dalam seni populer atau seni massa yang dihasilkan oleh kebudayaan industri adalah repetisi atau pengulangan-pengulangan dalam seni tersebut. Ideologi yang menjadi latar belakang seni massa adalah ideologi bisnis atau kapital. Oleh karena itulah, Adorno memandang bahwa seni yang telah terpengaruh kebudayaan industri bersifat rendah.

Berbeda dengan Adorno, Banjamin tidak memandang seni populer dengan nada negatif. Karya seni memang akan kehilangan aura dan otonominya. Meskipun demikian, nilai ritual seni digantikan dengan nilai pamernya. Reproduksi mekanis seni mengubah reaksi massa terhadap seni dengan memberikan mereka kesempatan untuk berpartisipasi dalam resepsi maupun apresiasi karena seni-seni populer lebih mudah diakses dan memberikan mereka peranan dalam penilaian kritisnya.

Titik temu dari perdebatan tersebut terletak pada prinsip dari seni populer, yaitu repetisi dan reproduksi. Kebaruan tidak lebih penting dari pemenuhan selera pasar (konsumen). Dalam 
satu periode tertentu akan ditemukan produksi karya sastra yang seragam atau bertipe sama, misalnya cerita cinta remaja karya Hilman Hariwijaya di tahun 1980-an atau cerita yang bertensi birahi karya Fredy S. di tahun 1990-an. Tidak ada perubahan tematik ataupun gagasan dalam karya-karya tersebut, yang ada hanya produksi karya-karya yang setipe karena pasar memang menghendaki demikian. Dalam kaitannya dengan Suparto Brata, novel MSA ini merupakan epigon dari novel Bumi Manusia karya Pramoedya.

Perbedaan selanjutnya terletak pada eksplorasi tema cinta. Persoalan cinta yang acap kali hadir dalam karya sastra juga memiliki perbedaan posisi dalam sastra serius dan sastra populer. Dalam sastra serius cinta hadir sebagai 'bumbu penyedap' saja, seringkali hanya sebagai penyusunan plot cerita, dan dalam porsi yang tidak dominan. Dalam sastra populer justru berlaku sebaliknya. Cinta hadir dalam porsi yang dominan dan menjadi pusat cerita. Cinta dalah persoalan ringan yang seringkali membuat orang merasa terharu biru.

Selain persoalan cinta, perbedaaan antara sastra serius dan populer terletak pada ending. Cerita dalam sastra populer diakhiri dengan kebahagiaan pada tokoh utama (happy ending). Hal tersebut dikarena tujuan utama dari sastra populer adalah sebagai karya hiburan. Pembaca akan menyenangi sebuah cerita yang diakhiri dengan kemenangan tokoh utama, yang umumnya baik, dan kekalahan pada tokoh jahat. Sastra 'serius' tidak dibebani oleh ending yang demikian. Penulis sastra 'serius' justru akan mempermainkan ending untuk membuka kemungkinan pemaknaan. Oleh karenanya, dalam sastra serius akan dijumpai karya sastra dengan akhir terbuka atau menggantung (open ending).

Persoalan apakah sebuah karya sastra masuk dalam kategori sastra 'serius' atau populer juga dapat dilihat dari unsur-unsur atau formula yang digunakan dalam cerita. Salah satu formula yang masuk dalam kategori sastra populer adalah formula cerita detektif. Dalam kaitannya dengan ending, cerita detektif cernderung diakhiri dengan pengungkapan kasus serta penjelasan terhadap misteri oleh tokoh detektif. Formula cerita detektif ini akan dijelaskan lebih rinci karena Suparto Brata, dalam sastra Jawa, dikenal sebagai pembaharu sastra dengan cerita-cerita detektifnya.

\section{FORMULA² CERITA DETEKTIF}

\footnotetext{
${ }^{2}$ Kata 'formula' merupakan sebutan untuk unsur-unsur karya sastra dalam konteks fiksi populer. Cawelti mendefinisikan formula sebagai kombinasi atau sintesis dari sejumlah konvensi kultural yang spesifik dengan bentuk cerita universal atau arketipe (Adi, 2011: 209)
} 
Cawelti dalam buku Romance, Detective and Mystery (1976) menjelaskan secara rinci mengenai formula cerita detektif dan perkembangannya. Menurut Cawelti (1976:43) misteri menjadi formula utama dalam cerita detektif klasik, sedangkan dalam cerita petualangan, roman, dan melodrama, misteri hanya sebagai prinsip pengganti (subsidiary), bukan sebagai prinsip yang dominan. Dengan bahasa berbeda, Mangunwijaya (1999: 104) menerangkan bahwa membaca novel detektif memanglah suatu pencerabutan diri ke dalam suatu gugusan dunia penuh pertanyaan: Siapa pembunuhnya? Siapa pencurinya? Siapa yang akan menegakkan kembali keadilan lewat penelanjangan si salah? Mengkalkulasi, menduga, mengira-ngira, dan menemukan "si pelaku yang bersalah", yang tentunya dibuat serba tersembunyi, terselubung, misteri, dan sebagainya, itulah watak cerita detektif.

Formula cerita detektif klasik dapat digambarkan sebagai cara konvensional mendefinisikan dan mengembangkan jenis situasi atau situasi-situasi tertentu, pola tindakan atau perkembangan situasi tersebut, kelompok tokoh tertentu dan hubungan antara mereka, dan pengaturan atau tipe pengaturan yang sesuai dengan tokoh dan tindakan (Cawelti, 1976: 80). Berdasarkan analisa terhadap karya Edgar Alan Poe ditemukan empat formula dalam cerita detektif klasik, yaitu situasi, pola tindakan, tokoh dan relasi, setting (tempat).

Situasi. Cerita detektif klasik dimulai dengan kejahatan yang belum terpecahkan dan bergerak menuju penjelasan misteri. Poe mendefinisikan dua jenis utama dari kejahatan yang banyak dijadikan dasar dalam sastra detektif, yaitu pembunuhan, sering dengan nada (nuansa) seksual atau mengerikan, dan kejahatan yang berhubungan dengan intrik politik (Cawelti, 1976: 80-81).

Pola tindakan. Sebagaimana disebutkan oleh Poe, pusat formula cerita detektif terletak pada investigasi detektif dan solusi dari kejahatan yang terjadi. Di sini dijelaskan terdapat enam tahap pola tindakan, yaitu (a) pengantar/pengenalan detektif, (b) pembunuhan dan petunjukpetunjuk, (c) investigasi, (d) pernyataan jawaban, (e) penjabaran/penjelasan jawaban, (f) akhir cerita. Bagian-bagian itu tidak selalu muncul secara berurutan dan kadang-kadang antara satu bagian menyatu dengan bagian lainnya (Cawelti, 1976: 81-82).

Tokoh dan relasi. Sebagaimana didefinisikan Poe, cerita detektif klasik memerlukan empat peran utama, yaitu (a) korban, (b) penjahat, (c) detektif, dan (d) pihak yang terancam tetapi tidak mampu memecahkannya. Pada perkembangannya, penulis-penulis mengurai peran-peran tersebut, dan dalam kasus tertentu mencapurkannya, namun secara keseluruhan masih dapat dikatakan 
bahwa mustahil dapat menciptakan cerita detektif tanpa relasi implisit peran-peran tersebut (Cawelti, 1976: 91).

Setting (tempat). Cerita detektif klasik, sebagaimana dalam cerita Poe, mengambil satu tempat terisolasi (tertutup) pada sebuah tempat yang lebih luas, misalnya dalam apartemen di tengah kota (Cawelti, 1976: 96-97). Cerita detektif ini, pada akhirnya, sering disebut sebagai Impossible Crime (kejahatan yang tidak mungkin) atau sering disebut sebagai locked room mystery (misteri kamar tertutup).

Selanjutnya, berdasakan analisa terhadap karya Agatha Cristie, Dorothy Sayers, dan Georges Simenon, dalam cerita detektif klasik minimal memenuhi tiga kriteria, yaitu (1) harus ada

misteri tentang tindak kejahatan yang disembunyikan dari pembaca atau dari tokoh protagonis sampai dengan akhir cerita; (2) struktur cerita berisi tentang penyelidikan fakta-fakta yang tersembunyi dengan tokoh protagonis sebagai pelaku dan investigasinya merupakan pusat tindakan dalam cerita; dan (3) fakta-fakta yang tesembunyi harus dipecahkan pada akhir cerita (Cawelti, 1976: 132).

Jenis cerita detektif lainnya adalah cerita detektif hard-boiled (The Hard-Boiled Detective Story). Formula hard-boiled hampir sama dengan kerangka utama cerita detektif klasik, yaitu dimulai dari pengenalan detektif dan pemunculan kejahatan, kemudian investigasi, hingga sampai pada solusi/jawaban dan penangkapan penjahat (Cawelti, 1976: 142). Sebagaimana cerita klasik, formula hard-boiled dikembangkan melalui empat tokoh utama, yaitu (a) korban-korban, (b) penjahat, (c) detektif, dan (d) mereka yang terlibat dalam kejahatan, tetapi tidak mampu menyelesaikan masalah-masalah yang ada, sekelompok yang melibatkan polisi, tersangka, dan sebagainya - sebenarnya, sekumpulan tokoh yang mewakili masyarakat dalam cerita (Cawelti, 1976: 147). Dalam cerita detektif hard-boiled, pelaku memiliki keterlibatan dengan dunia kriminal. Penjahat seringkali memiliki hubungan dengan organisasi kejahatan yang besar (Cawelti, 1976: 148).

\section{PEMBAHASAN}

\section{A. Nggolek Susuhe Angin: Perjuangan Uang dan Cinta}

Golek susuhe angin atau 'mencari sarang angin' merupakan misi Darwan, sebagai tokoh utama, dalam kehidupannya di Surabaya. Istilah susuhe angin atau 'sarang angin' merupakan istilah yang diambil dari cerita pewayangan, yaitu ketika Bima disuruh oleh gurunya, Durna, untuk 
mencari mencari ilmu sejati bernama Sangkan Paraning Dumadi yang bertempat di Kayugung Susuhe Angin yang berada dibawah Gunung Candradimuka. Kata 'susuhe angin' merupakan metafor dari nafas atau lebih jauh dapat diartikan sebagai kehidupan, sebab nafas adalah tanda bahwa manusia hidup. Maka 'mencari sarang angin' merupakan misi Darwan dalam mencari kehidupannya sendiri.

Misi mencari sarang angin adalah misi yang dikerjakan Darwan untuk hidup mandiri tanpa tergantung pada kekayaan dan kekuasaan Kanjeng Ramanya. Darwan juga ingin mengubah kehidupan keraton yang dianggapnya terlalu feodal dan telah ketinggalan zaman. Oleh karenanya, ketika menerima surat balasan dari Tuan Ayat, pimpinan surat kabar berbahasa Jawa Dagblad Expres, Darwan segera pamit kepada Kanjeng Ramanya dan bergegas menuju Surabaya. Di samping itu, Darwan memutuskan untuk pergi ke Surabaya lantaran sakit hati dituduh menyukai selir Kanjeng Ramanya.

Surabaya, bagi Darwan, merupakan sebuah ruang atau arena untuk berjuang untuk hidup: uang dan cinta. Dalam perjuangannya, Darwan memaksimalkan modal kultural, yaitu kemahiran menulis dan kemahiran berbahasa Belanda yang diperoleh dari pendidikan. Darwan tidak memaksimalkan modal ekonomi yang berupa kekayaan keluarganya. Dengan modal kultural dan habitusnya sebagai seorang bangsawan dan pemuda terpelajar yang tampak dari cara berpakaian dengan menggunakan kemeja, pantalon, dan sepatu (halaman 7), Darwan memulai praktik sosialnya sebagai seorang wartawan. Modal-modal kultural ini selanjutnya mempengaruhi terciptanya modal-modal yang lain.

Kedatangan Darwan ke Surabaya untuk bekerja menjadi wartawan di surat kabar Dagblad Expres bermodal kemahiran menulis cerita bersambung. Darwan membayangkan bahwa Dagblad Expres merupakan surat kabar besar yang akan memberikannya gaji besar. Namun perkiraan Darwan keliru. Dagblad Express bukanlah tempat untuk mendapatkan uang, tetapi sebagai ruang untuk menyampaikan pikiran dan gagasan demi kemajuan bangsa. Oleh karena itulah, redakturredaktur di Dagblad Express juga bekerja di tempat lain guna mendapatkan uang untuk mencukupi hidup.

Kondisi tersebut tidak membuat Darwan mengurungkan niatnya untuk bekerja di Dagblad Express. Ada rasa gengsi bila harus kembali ke Surakarta. Darwan justru terlecut semangat untuk membuktikan diri bahwa dia dapat hidup tanpa tergantung pada harta kekayaan dan kekuasaan 
Rama Kanjengnya. Ketertarikan pada seorang rekan kerja, Yayi, juga berperan penting dalam keputusan Darwan.

Karena modal ekonominya tidak kuat, Darwan memilih tinggal di rumah Rokhim (rekan kerjanya). Dalam hal ini Darwan menggunakan modal sosialnya. Pemilihan tempat pondokan ini juga merupakan bentuk strategi Darwan untuk menekan beban ekonomi, mengenali lebih dekat arena yang menjadi ruang bertarungnya, dan untuk melindungi Rokhayah (adik Rokhim) dari sikap kasar Rokhim.

Langkah kongkret yang ditempuh Darwan dalam upaya mengenali Surabaya adalah dengan menuliskan berita dari hasil wawancara masyarakat pinggiran kota tentang kota Surabaya. Darwan berpikir bahwa hal ini sekaligus merupakan usaha penulisan sejarah sehari-hari masyarakat Surabaya (penulisan sejarah mazhab Anneles). Usaha ini ditolah oleh adik pimpinan Dagblad Express karena dianggap tidak sesuai dengan visi surat kabar.

Dalam suasana penuh kekecewaan, Darwan bertemu Steffie Van Daal (wartanan surat kabar Soerabaiacsh Nieuws-Handelsblad) ketika tengah liputan berita kebakaran. Dalam pertemuan ini Darwan menunjukkan kecakapannya dalam bahasa Belanda. Melihat kepandaian Darwan, Van Daal menganjurkan Darwan untuk menulis dalam bahasa Belanda dan mengirimkan tulisannya ke Soerabaiacsh Nieuws-Handelsblad. Darwan melaksanakan anjuran tersebut. Tulisan Darwan dimuat, bahkan diberi kolom khusus dan mendapatkan honorarium yang jauh lebih tinggi dari gaji di Dagblad Express. Dengan uang tersebut Darwan akhirnya bisa mendapatkan tempat pondokan yang lebih baik.

Pertemuan Darwan dan Van Daal menunjukkan bahwa satu jenis modal seorang agen dapat mempengaruhi munculnya jenis modal lainnya. Modal kultural Darwan dalam bentuk ketrampilan menulis dan kemahiran berbahasa Belanda memunculkan dan menguatkan modal sosial, yaitu relasinya dengan Van Daal. Dari proses tersebut Darwan mendapatkan laba ekonomi, yang juga menjadi modal ekonomi sehingga mendapatkan tempat pondokan baru.

Hubungan Darwan dan Van Daal juga banyak memberikan keuntungan untuk Darwan. Darwan mendapatkan informasi tentang kemajuan jaman, yaitu mesin ketik dan mengemudi mobil. Dengan latihan yang tekun, Darwan dapat menguasai ketrampilan tersebut. Di samping itu, Darwan juga dikenal oleh seorang administrasi Soerabaiacsh Nieuws-Handelsblad yang nantinya berpengaruh pada kelanjutan praktik sosialnya. Pada masa pendudukan Jepang, Zaki 
merekomendasikan Darwan untuk menjadi redaktur Soeara Asia, dan pada masa malaise memberikan Darwan sekarung beras.

Di akhir cerita, Darwan meninggalkan Surabaya dan kembali ke Kanjeng Ramanya di Surakarta. Jika ditinjau dari segi ekonomi dapat dikatakan bahwa usaha Darwan telah mengalami kegagalan. Satu-satunya keberhasilan Darwan dalam misi golek susuhe angin (mencari sarang angin) adalah kemantapannya untuk bekerja di bidang jurnalistik. Di Surakarta, Darwan menjadi penulis lepas di surat kabar Kedaulatan Rakyat Yogyakarta.

Dalam pencarian cinta, Darwan juga tidak mendapatkan hasil sebagaimana harapannya. Ia mencintai Yayi dan berharap untuk menhikahinya. Yayi justru kawin dengan Slamet. Ketika menjadi janda dan terbuka peluang untuk mengawininya, Yayi justru mati karena dihajar oleh Kenpeihok. Darwan akhirnya kawin denan Rokhayah yang sebenarnya kurang dicintainya.

\section{B. Pemanfaatan Formula Cerita Detektif}

Untuk mengetahui formula yang digunakan dalam MSA, maka peneliti memulai analisis tentang fokalisasi ${ }^{3}$ dan narator. Genette (1980: 189-190) membedakan fokalisasi menjadi tiga jenis, yaitu pertama cerita tidak berfokal atau berfokal nol, yaitu fokalisasi dengan pemandang mutlak berada di luar cerita; kedua cerita berfokal internal, yaitu fokalisasi dengan pemandang berada dalam cerita atau pemandang merupakan salah satu tokoh dalam cerita. Fokalisasi jenis ini dibedakan menjadi tiga jenis, yaitu (a) fixed (tetap), dimana seluruh cerita dipandang melalui sudut pandang salah satu tokoh saja, (b) variable (berubah), dimana terdapat pergantian pemandang dari satu tokoh ke tokoh lain dalam cerita, dan (c) multiple (jamak), dimana sebuah cerita dipandang melalui sudut pandang beberapa tokoh; ketiga cerita berfokal eksternal, yaitu fokalisasi dengan posisi pemandang sama dengan posisi pemandang pada cerita berfokal internal. Bedanya, di dalam cerita berfokal eksternal, pembaca tidak mengetahui yang dipikirkan atau dirasakan pemandang. Jadi, fokalisasi berkaitan dengan posisi narator dalam sebuah cerita.

Narator adalah sosok yang menjadi jurubicara dalam sebuah cerita. Sosok narator tidak selalu identik dengan sosok pengarang. Berkaitan dengan sosok narator, Genette (1980: 244-245) membedakan menjadi dua tipe, yaitu narator yang tidak hadir dalam cerita yang disebut heterodiegetic, dan narator yang hadir sebagai tokoh dalam cerita yang disampaikannya yang

\footnotetext{
${ }^{3}$ Fokalisasi merupakan istilah yang dikembangkan oleh Gérard Genette berdasarkan beberapa teori sebelumnya yang oleh Genette disebut sebagai perspective (sudut pandang): Cleanth Brooks dan Robert Penn, F. K. Stanzel, Ishmael dan Strether, Norman Friedman, Wayne Booth, Bertil Romberg, Jean Pouillon dan Tzvetan Todorov (Genette, 1980: 185-189)
} 
disebut homodiegetic. Dalam posisi sebagai juru cerita, narator memang dapat berada di luar maupun di dalam cerita. Narator yang di luar cerita mengacu pada author-narrator (pengarang cerita) atau implied author (pengarang implisit), sedang narator dalam cerita mengacu pada character-narrator (tokoh sebagai narator), baik menceritakan ceritanya sendiri atau cerita tokoh lain.

Secara keseluruhan, novel MSA merupakan cerita berfokal eksternal. Narator dapat dirasakan kehadirannya tetapi tidak mewakili tokoh dalam cerita. Narator merupakan omniscient author atau pengarang yang serba tahu yang berusaha menghadirkan peristiwa-peristiwa yang dialami oleh tokoh-tokoh dalam cerita. Narator hadir sebagai seorang pencerita sekaligus pengamat: mengetahui, mengenali, dan mengorganisasi fakta-fakta yang diceritakan, pemikiran dan perasaan tokoh-tokohnya. Narator juga memiliki keleluasaan perlbagai fakta di tempat dan waktu. Keserbatahuan narator tersebut paling tampak pada kutipan berikut:

Rokhim merasa tersaingi oleh Darwan. Ia tidak mau kalah, tidak mau menyerah. Pada suatu hari nanti, Rokhim akan menjadi seperti Darwan. Mungkin akan melebihi. Dibawanya Darwan ke dekatnya dan mondok di rumahnya, untuk dipelajari bagaimana cara Darwan hidup, berpikir, dan bertingkah.

Darwan sadar akan hal itu. Ia tidak sakit hati seandainya itu nanti benar-benar terjadi. Sayangnya, Darwan tahu persih posisi Rokhim terlalu jauh di bawah Darwan. Akan sulit mengejar ketertinggalannya. Ketinggalan dalam hal pemilikan kemampuan, kekayaan, berpikir, dan berbudaya. [...] (Brata, 2005: 85)

Terlihat jelas bagaimana narator mengetahui pikiran tokoh-tokohnya, yaitu Rokhim dan Darwan. Model penceritaan seperti tersebut di atas merupakan model penceritaan yang mendominasi cerita dalam MSA. Narator tidak sekedar menceritakan dan mengetahui pikiran tokoh, tetapi juga mengkonstruksi tokoh dan penokohannya. Pemahaman tokoh satu terhadap tokoh lain tidak disebabkan oleh interaksi antartokoh, tetapi dikonstruksi oleh narator. Hal ini cukup untuk menunjukkan bahwa narator memang benar-benar berada di luar cerita, sekaligus menunjukkan bahwa narator adalah author-narrator (pengarang cerita).

Dalam hubungannya dengan pembaca, narator menciptakan misteri, semacam teka-teki tentang berbagai persoalan yang hendak dialami tokoh-tokoh dalam cerita. Narator dalam MSA menghadirkan stimulus berupa pertanyaan-pertanyaan yang membuka beragam kemungkinan 
jawaban. Pertanyaan-pertanyaan tersebut hadir hampir di seluruh bagian (bab) novel ${ }^{4}$. Beberapa contoh pertanyaan dapat disimak dalam kutipan di bawah ini:

Keadaan beginikah tempat ia bekerja, tempat ia memilih pekerjaan? Apa yang mau ditekuni? Apa yang mau dikejar? Apa yang dicari? Hikmah hidup apa yang mau diperjuangkan? (Brata, 2005: 6)

Ya, apakah yang dikerjakan Yayi di luar pekerjaannya di Dagblad Express? Dengan pakaian begitu modern, mengenakan sepatu, berkalung emas, dan membawa tas cangkong, tentulah tidak mungkin dia hanya hidup dengan honorarium sebagai wartawan Dagblad Express! Lalu, bekerja apakah sambilannya? Atau, di Dagblad Express ini kerja sambilannya, di luar sana bahkan kerja pokonya? Darawn mau bertanya kepada Slmaet, tetapi takut-takut kalau Slamet tidak menjawab jujur. (Brata, 2005: 195)

Sungguh, Darwan tidak tahu! Mengapa secepat itu polisi mengetahui tempat persembunyian Slamet. Apakah Slaemt-Yayi memang sudah diamat-amati sejak lama, dan diintai sejak malam tadi setelah ketemu rumahnya? Tapi, mengapa tidak justru ketika mereka masuk di dalam rumahnya di sergap? Dan, mengapa sampai detik ini polisi tidak menggeledah rumahnya Yayi? Apakah Yayi akhirnya juga ditangkap di kereta api? Darwan kalut pikirannya. Dan, sekarang mau berbuat apa juga tidak tahu. (Brata, 2005: 373)

Terdapat dua kemungkinan mengenai frekuensi narasi model pertanyaan dalam MSA, yaitu pertama, karena sebelum dijadikan bentuk buku (novel), MSA dipublikasikan secara bersambung di koran (Jawa Pos); kedua, sebagai tanda bahwa MSA merupakan cerita detektif. Sebuah cerita bersambung menuntut cerita yang hadir pada tiap-tiap edisi pemuatan harus dapat menumbuhkan rasa keingintahuan pembaca terhadap kelanjutan cerita. Cerita harus memiliki misteri yang tertunda solusinya sebagaimana dalam sebuah cerita detektif. Dengan demikian narasi-narasi pertanyaan dalam MSA merupakan penghubung menuju cerita selanjutnya, sekaligus dapat dibaca sebagai usaha untuk menghadirkan sisi misteri cerita.

Dominasi misteri tersebut juga merupakan tanda awal bahwa MSA menggunakan formula cerita detektif. Praduga ini diperkuat dengan teknik fokalisasi yang digunakan dalam MSA, yaitu fokalisasi eksternal, dan posisi narator yang berada di luar cerita. Dengan menarasikan cerita dari sudut pandang yang melihat tindakan detektif tetapi tidak berpartisipasi dalam persepsi atau proses

\footnotetext{
${ }^{4}$ Peneliti mencatat narasi yang berbentuk pertanyaan muncul di novel pada halaman 6, 14, 19, 24, 26, 27, 69, 71, 74, 75 ,
} 
penalarannya, penulis dapat lebih mudah menyesatkan perhatian pembaca dan dengan demikian menjaganya dari pemecahan kejahatan secara prematur. Jika menggunakan sudut pandang detektif, penulis memiliki kesulitan untuk menjaga rahasia misteri tanpa membuat batas tidak wajar dan acak pada apa yang ditunjukkan kepada proses penalaran detektif (Cawelti, 1976: 83).

Meskipun terdapat pengembangan-pengembangan cerita $^{5}$, formula cerita detektif menjadi formula utama novel MSA baik dalam penyusunan plot, penciptaan tokoh, pembangunan klimaks, maupuan penyelesaian masalah. Kasus yang dihadirkan dalam MSA adalah penangkapan Slamet oleh P.I.D dan kasus penghajaran Yayi oleh Kenpeihok yang menyebabkan kematian. Dalam kerangka cerita detektif, MSA menempatkan Slamet dan Yayi sebagai korban, Rokhim sebagai penjahat, Sajiwa sebagai detektif, dan Darwan sebagai pihak yang terancam tetapi tidak mampu memecahkan masalah.

Dari awal cerita telah ditunjukkan bahwa Slamet dan Yayi (korban) bermasalah dengan Rokhim (penjahat). Yayi menilai bahwa Rokhim adalah laki-laki yang serakah (hlm. 23). Tidak ada penjelasan tentang sikap Yayi yang begitu membenci Rokhim. Sampai akhir cerita tidak diungkapkan adanya persoalan yang lebih kongkret antara Yayi dengan Rokhim, selain kebencian. Begitu pula antara Slamet dan Rokhim. Dalam MSA diceritakan bahwa Rokhim begitu membenci Slamet yang dinilainya sebagai orang yang sombong (hlm. 122-123).

Kebencian menjadi motif utama dalam proses kejahatan yang dilakukan Rokhim. Meski digambarkan memiliki ketekunan dan cita-cita yang tinggi, tokoh Rokhim lebih banyak dihadirkan sebagai tokoh yang memiliki sifat buruk: keras, tidak terpelajar, bergaya seperti penguasa, cepat marah, dan suka mabuk. Penggambaran sifat dan sikap Rokhim tidak hanya ditunjukkan melalui peristiwa dan tanggapan tokoh-tokoh lain, tetapi diperjelas oleh cerita narator. Narator memang membentuk tokoh Rokhim sebagai tokoh jahat yang pantas dibenci oleh pembaca.

Berbeda dengan Rokhim, Slamet dan Yayi digambarkan sebagai pemuda yang cerdas dan terpelajar yang memiliki kepedulian terhadap kemajuan bangsa. Mereka bekerja redaktur di Dagblad Express. Bagi mereka, Dagblad Express merupakan ruang menyampaikan pikiran dan gagasan guna menggerakkan masyarakat ke arah yang lebih baik (hlm. 7). Dagblad Express bukanlah ruang untuk mencari uang. Oleh karena itu, redaktur di Dagblad Express, termasuk Slamet dan Yayi, hanya bekerja separuh waktu dan memiliki pekerjaan di luar yang lebih besar

\footnotetext{
${ }^{5}$ Memang secara sekilas hal ini tidak tampak karena tertutup oleh penghadiran latar belakang sejarah nasional Indonesia dan lokalitas Surabaya dalam porsi yang cukup besar.
} 
gajinya. Di luar Dagblad Express Yayi memiliki kegiatan di Jong Java. ${ }^{6}$ Sedangkan kegiatan Slamet masih menjadi mesteri (di bagian kelima, Bencana, misteri ini baru dibuka).

Di luar Dagblad Express Slamet dan Yayi memiliki hubungan. Pada bagian pertama (Dagblad Express) terdapat sebuah clue (petunjuk): “... Mas, kemarin pemilik toko Cioda menghubungi aku. Ada tugas serius untuk kita berdua...!" (hlm. 24). Berita dari Yayi yang disampikan kepada Slamet ini menjadi awal misteri kegiatan Slamet dan Yayi ketika Slamet membalasnya, "Ssstt! Garaplah naskahmu. Kita bicarakan Cioda di luar sini!" (hlm. 24). Cioda menjadi clue untuk misteri dan berkaitan dengan kematian Slamet.

Kegiatan Slamet di luar Dagblad Exprees tetap menjadi misteri bagi Darwan. Dengan menghubungkannya dengan Cioda dan pembicaraan Slamet tentang bangsa, Darwan menduga bahwa Slamet terlibat dalam kelompok atau patij garis keras. Hal ini juga dibicarakan dengan Rokhim. Rokhim mengusulkan untuk melaporkan Slamet ke P.I.D. karena menilai Slamet membahayakan orang-orang dekatnya (hlm. 120-121). Rokhim mengakui memiliki teman dari Kedungrukem yang menjadi reserse (hlm. 121). Peristiwa ini menjadi salah satu clue dalam kasus penangkapan Slamet.

Misteri tentang kegiatan Slamet di luar Dagblad Express semakin menambah besar rasa penasaran Darwan. Pada suatu kesempatan, Slamet mengatakan pada Darwan bahwa dia sibuk mengikuti kursus radio. Namun Darwan berpikir bahwa hal ini aneh, karena kursus justru akan mengeluarkan uang, sedang kegiatan di luar Dagblad Express adalah usaha untuk menambah uang (hlm. 189). Radio ini ternyata menjadi petunjuk Darwan tentang keterlibatan Slamet dalam sidang perkara penyelundupan radio oleh nelayan di Gresik. Penyelundupan tersebut diduga berkaitan dengan spionase yang dilakukan oleh musuh perintah Hindia Belanda. Slamet ada dalam sidang tersebut untuk mendampingi seorang pokrol (pengacara) yang membela nelayan. Slamet menyuruh Darwan untuk merahasiakan kehadirannya di sidang tersebut (dengan mengirimkan sebuah pesan rahasia dan, setelahnya, permintaan langsung).

Dugaan Darwan ternyata benar. Slamet dan Yayi, yang akhirnya menikah, terlibat dalam penyelundupan radio tersebut. Tugas dari Cioda yang dimaksudkan adalah menjadi mata-mata, menjadi spion. Kegiatan ini diketahui oleh P.I.D. Pada suatu pagi, Slamet dan Yayi ke rumah Darwan untuk bersembunyi dari kejaran P.I.D.. Darwan menyarankan untuk sementara Slamet dan

\footnotetext{
${ }^{6}$ Nama perkumpulan pemuda Jawa
} 
Yayi harus berpisah. Slamet mondok di rumah Rokhim dengan alasan sedang bertengkar dengan Yayi, sedangkan Yayi disuruh bersembunyi di rumah Darwan di Surakarta.

Di rumah Rokhim inilah akhirnya Slamet ditangkap oleh polisi tak berseragam (kemungkinan adalah P.I.D.). Mengenai hal ini, Darwan dan Yayi menceritakan kepada Sajiwa. Menurutnya terdapat dua kemungkinan, yaitu bahwa Slamet telah diikuti oleh polisi ketika ke rumah Rokhim atau ada yang melaporkan keberadaan Slamet. Kemungkinan pertama akhirnya dieliminasi sebab Darwan yakin bahwa tidak ada polisi yang mengikuti, kalaupun ada, tentunya Yayi juga akan ditangkap. Jadi kemungkinan ada orang yang sengaja melaporkan keberadaan Slamet. Menurut analisis Sajiawa, orang-orang yang patut dijadikan tersangka adalah Darwan, Yayi, Rokhim, Jayajais (bapak Rokhim), Ning Rokh (emak Rokhim), dan Rokhayah (adik Rokhim). Dilihat dari motif dan kesempatan untuk melapor, mereka menambil kesimpulan bahwa Rokhim merupakan tersangka utama (492-494).

Berbeda dengan Slamet, Yayi ternyata selamat. Setelah Indonesia dikuasai oleh Jepang, Yayi kembali ke Surabaya untuk mengadakan pameran lukisan. Pada waktu pameran lukisan, datang Kenpeitai dan Kenpeihok untuk melakukan pemeriksaan. Seorang Kenpeihok bernama Toronadie (dalam huruf katakana) menemukan ada emblem bendera Belanda di tas Yayi. Di emblem tersebut ada tulisan: Jubileum 1913-1938 dan Kolff \& Co. Drukkerij (Peringatan 25 tahu dan Percetakan Kolff \& Co). Yayi akhirnya ditangkap oleh Kenpetai dan Kenpeihok karena dianggap sebagai mata-mata musuh, meskipun ia mengaku bahwa benda tersebut bukan miliknya (hlm. 539-543). Setelah 3 hari di tahan, dengan bantuan memo dari Akhisita, Yayi dapat dikeluarkan dengan kondisi tubuh terluka parah. Sehari setelahnya, Yayi meninggal di rumah Darwan. Sebelum meninggal Yayi sempat memberikan sebuah petunjuk, yaitu Tirtanadi (hlm. $562)$.

Darwan dan Sajiwo menganalisis bahwa Yayi penangkapan Yayi adalah seuah kesengajaan. Emblem yang ada di tas Yayi adalah jebakan. Namun mereka tidak mengetahui pelakunya. Hanya ada petunjuk: emblem dan Tirnonadi. Pada bagian ketujuh (Revolusi), Darwan dan Sajiwa menemukan banyak emblem yang sama di percetakan tempat Darwan bekerja. Peristiwa ini merupakan petunjuk bahwa Rokhim adalah satu-satunya tersangka dalam kasus penangkapan Yayi karena hanya Rokhim yang pernah bekerja di percetakan tersebut. Motif dari Rokhim adalah kebencian (hlm. 648). 
Misteri penangkapan Slamet dan Yayi terbuka ketika Darwan bertemu dengan Murdanu (redaktur Dagblad Express) yang telah menjadi tentara. Diceritakan oleh Murdanu bahwa prosesnya menjadi tentara lantaran dia membunuh salah satu Kenpeihok yang bernama Turnadi. Dia juga menceritkan bahwa Turnadi adalah reserse yang menangkap Slamet di rumah Rokhim. Rokhim yang memberitahu keberadaan Slamet (hlm. 680). Kenpeihok itu juga yang telah menangkap Yayi. Darwan mengetahuinya dari ciri fisik yang disampaikan Murdanu dan nama Kenpeihok tersebut, Turnadi. 'Turnadi' jika ditulis dalam huruf katakana akan dibaca menjadi 'Torunadi', dan pesan singkat Yayi sebelum mati bukanlah "Tirtonardi' tetapi 'Turnadi' (hlm. $681)$.

Di akhir cerita, Rokhim menjebak Darwan dan hendak membunuhnya. Rokhim masuk PKI dan menganggap Darwan adalah antek Soekarno (hlm. 709). Namun sebelum semua rencana Rokhim tuntas, Sajiwa datang, menembak, dan menangkap Rokhim. Rokhim juga mengakui bahwa emblem yang dibawa Yayi adalah jebakan darinya. Rokhayah disuruh menaruh emblem tersebut dalam tas Yayi sebagai jimat agar Yayi menjauh dari Darwan.

MSA memang tidak memanfaatkan formula cerita detektif secara penuh dan tidak sama persis. Darwan sebagai tokoh utama tidak dijadikan sebagai detektif, tetapi justru sebagai tokoh yang terancam. Sajiwa menjadi tokoh yang bertindak dengan gaya detektif, tetapi tidak melakukan investigasi. Petunjuk-petunjuk yang ada tidak didapatkan melalui sebuah pencarian, tetapi seolaholah hadir tanpa kesengajaan. Meskipun demikian, cerita ini dikemas sebagai sebuah cerita detektif dengan mengoptimalkan unsur misterinya.

Formula cerita detektif juga menjadi salah satu modal dan strategi tekstual lain yang digunakan oleh Suparto Brata. Modal ini lahir dari pendidikan Suparto Brata yang membentuknya sebagai individu yang memiliki kegemaran membaca buku dan majalah, terutama sastra, dan dapat mengakses buku-buku bacaan sastra. Mengenai hal tersebut Suparto Brata menceritakan:

Saya yang dianugerahi oleh Tuhan kepandaian menulis. Saya memilih menulis karya sastra, sebab sastra adalah bahan bacaan yang menarik. Dari buku-buku tadi saya mulai kenal Agatha Christie, Georges Simenon, Erle Stanley Gardner, Raymond Chandler, dan banyak lagi para penulis cerita detektif. Saya jadi terpengaruh, karena cerita detektif lebih menggairahkan saya untuk membacanya sekalipun bahasa Inggris. (Brata, 2011: 18-19)

Cerita-cerita detektif tersebut berpengaruh terhadap karya-karya Suparto Brata, baik yang berbahasa Indonesia maupun berbahasa Jawa. Formula cerita detektif dimanfaatkan secara 
maksimal pada novel Detektif Handoko. Beberapa novel lain, termasuk MSA, diidentifikasi juga memanfaatkan formula cerita detektif, meskipun tidak secara penuh.

\section{SIMPULAN}

Berdasar analisis di atas dapat disimpulkan bahwa MSA memang merupakan karya sastra populer. Hal ini dibuktikan melalui dua temuan, yaitu penghadiran kisah cinta yang begitu dominan dan menjadi pusat cerita; juga pemanfaatan formula cerita detektif sebagai struktur penceritaan. Pilihan tema ${ }^{7}$ atau cara-cara artistik dengan memanfaatkan formula cerita detektif ini setidak-tidaknya dipengaruhi tiga hal, yaitu pertama kegemaran Suparto Brata membaca ceritacerita detektif seperti Agatha Cristie, Georges Sinemon, Reymond Chandler, dan lainnya; kedua karena dipengaruhi kesuksesan Suparto Brata di sastra Jawa yang dinilai memberikan pembaharuan yaitu dengan menciptakan cerita bersambung detektif yang berjudul Tanpa Tlacak (1962); dan ketiga karena pada era tahun 1980-an novel-novel detektif berkembang pesat sebagai salah satu jenis sastra Indonesia populer.

\section{DAFTAR PUSTAKA}

Adi, Ida Rochani. 2011. Fiksi Populer: Teori \& Metode Kajian. Yogyakarta: Pustaka Pelajar.

Brata, Suparto. 2005. Mencari Sarang Angin. Jakarta: Grasindo

Bourdieu, Pierre. 2010. Arena Produksi Kultural: Sebuah Kajian Sosiologi Budaya. Yogyakarta: Kreasi Wacana.

Cawelti, John G. 1976. Adventure, Mystery, and Romance: Formula Stories as Art and Popular Culture. Chicago: University of Chicago Press.

Gelder, Ken. 2004. Popular Fiction: The Logics and Prctices of a Literary Field. New York: Routledge.

Genette, Gerard. 1980. Narrative Discourse: An Essay in Method. Cornell: Cornell University Press.

Mangunwijaya, Y.B. 1999. Menjadi Generasi Pasca-Indonesia: Kegelisahan Y.B. Mangunwijaya. Yogyakarta: Kanisius.

\footnotetext{
${ }^{7}$ Menurut Bourdieu tema sesunguhnya dari sebuah karya seni tak lain dan tak bukan sebagai cara-cara artistik yang spesifik yang dipakai seniman dalam menggegam dunia, tanda-tanda yang tidak bisa disangkal mengenai penguasaannya terhadap seni (2010: 147).
} 